No 4078

Studia nad Autorytaryzmem i Totalitaryzmem 43, nr 4 Wrocław 2021

https://doi.org/10.19195/2300-7249.43.4.20

WITOLD KULESZA

ORCID: 0000-0003-2593-6801

Uniwersytet Łódzki

wkulesza@wpia.uni.lodz.pl

\title{
Sędziowie sądów specjalnych III Rzeszy i ich ,zdrowe poczucie narodowe”
}

Slowa kluczowe: III Rzesza, Sondergerichte, analogia iuris, Machtergreifung, Kieler Schule.

\author{
JUDGES OF THE SPECIAL COURTS OF THE THIRD REICH AND THEIR \\ "HEALTHY NATIONAL SENSE" (DAS GESUNDE VOLKSEMPFINDEN)
}

\begin{abstract}
German lawyers jointly supported the National Socialist authorities, assuming that the law was Hitler's will, resulting from the new criminal law being introduced, which violated the principles of nullum crimen sine lege and nulla poena sine lege. Judges of special courts (Sondergerichte) in the Third Reich applied criminal law according to a "healthy national sense" (das gesunde Volksempfinden), which usually meant heavy penalties, contrary to the elementary sense of justice. It was adopted as a rule that a crime is not only what is forbidden by regulations, but also everything that the authorities have not consented to. For any behaviour, even if not prohibited by law, the judges could sentence defendants to draconian punishments, at their "national discretion." Law professors justified the lawlessness created in the Third Reich by claiming that it was a rule of law (Rechtsstaat). The criminal law for Poles and Jews of 1941 provided for the death penalty for all manifestations of "hostile attitude" towards the German occupier. Polish forced labourers in the Reich were punished with death for violations of discipline and disobedience to the German oppressors. Poles displaced from occupied Poland were assigned to work in enterprises and farms in the Reich. The special court in Breslau sentenced to death a Pole who defended his pregnant beloved woman, forced to work beyond her strength and abused by the German housewife, as well as the unfortunate woman herself. The same court sentenced a Pole to death for trying to protect his 13-year-old son from a German farmer, who was forcing the child to perform work he was physically unable to carry out. Special-court judges continued their professional careers in West Germany after the war and did not bear any responsibility for their crimes.
\end{abstract}

Keywords: Third Reich, Sondergerichte, analogia iuris, Machtergreifung, Kieler Schule. 


\section{Wprowadzenie}

Ustanowione w 1933 roku sądy specjalne obsadzone zostały przez prawników, których Ingo Müller trafnie określił z historycznej perspektywy w tytule swego studium jako „strasznych jurystów” - „furchtbare Juristen”. "Zanim zaczęli oni ferować wyroki, powołując się na przepisy stanowiące w swej treści ustawowe bezprawie, ukończyli uniwersyteckie studia prawnicze, na których poznawali jako fundament wykładni i stosowania prawa karnego wyrażoną w wydaniu Leipziger Kommentar z 1925 roku tezę, że $§ 2$ StGB z 1871 roku gwarantuje „,nie ma czynu karalnego i nie ma kary bez ustawy, nullum crimen sine lege, nulla poena sine lege" ${ }^{\text {"2 }}$ Zasada ta w 1933 roku została zastąpiona hasłem głoszaccym, że całe niemieckie prawo i jego stosowanie będzie określane przez „duch narodowosocjalistycznego światopoglądu” („Geist des Nationalsozialistischen Weltanschaung") ${ }^{3}$. Owładnięci tym duchem sędziowie gwałcili elementarne zasady prawa karnego, wydając wyroki będące obrazą sprawiedliwości.

Równolegle $\mathrm{z}$ opracowaniem mającym ukazać węzłowe zagadnienia odpowiedzialności karnej sędziów i prokuratorów za współudział w wydawaniu zbrodniczych wyroków ${ }^{4}$ ukazała się w 2013 roku monograficzna publikacja zbiorowa pod redakcją Manfreda Görtemakera (historyka dziejów najnowszych) i Christopha Safferlinga (prawnika karnisty), zawierająca artykuły, których treść stanowiła doniosły wkład do badań nad pojęciem przestępczego naginania prawa przez służących III Rzeszy jurystów ${ }^{5}$. Obaj wyżej wymienieni autorzy stanęli na czele niezależnej komisji naukowej, powołanej w 2012 roku przez Ministerstwo Sprawiedliwości Republiki Federalnej Niemiec w celu zbadania, w jaki sposób odniesiono się do nazistowskiej przeszłości ministerialnych urzędników. Z końcem 2016 roku ukazało się ich wspólne monumentalne dzieło Die Akte Rosenburg. Das Bundesministerium der Justiz und die NS-Zeit, ukazujące dokumentalnie to, „co w okresie założycielskim Republiki Federalnej Niemiec działo się za murami

${ }^{1}$ I. Müller, Furchtbare Juristen. Die unbewältigte Vergangenheit unserer Justiz, München 1989.

2 A. Lobe, [w:] L. Ebermayer, A. Lobe, W. Rosenberg, Reichs-Strafgesetzbuch (Leipziger Kommentar), Berlin-Leipzig 1925, s. 109. Komentarz do § 2 StGB, głoszącego, że: „Czyn wówczas jedynie pociąga za sobą karę, gdy kara ta przed popełnieniem czynu była w ustawie przewidziana”, rozpoczynało zdanie: „Przepis wyraża na wstępie, że tylko na gruncie wyraźnego ustawowego przepisu może zostać orzeczona kara".

${ }^{3}$ B. Rüthers, Die Gesetzgebung - Vom „Dritten Reich“ zur Bundesrepublik Deutschland. Vierzehn Hypothesen, [w:] Die Rosenburg. Das Bundesministerium der Justiz und die NS-Vergangenheit - eine Bestandsaufnahme, red. M. Görtemaker, Ch. Safferling, Bonn 2013, s. 131.

${ }^{4}$ W. Kulesza, Crimen laesae iustitiae. Odpowiedzialność karna sędziów i prokuratorów za zbrodnie sądowe wedlug prawa norymberskiego, niemieckiego, austriackiego i polskiego, Łódź 2013.

5 Die Rosenburg. Das Bundesministerium der Justiz und die NS-Vergangenheit - eine Bestandsaufnahme, red. M. Görtemaker, Ch. Safferling, Bonn 2013. 
Federalnego Ministerstwa Sprawiedliwości, willi Rosenburg w Bonn"6. Od połowy 2017 roku rezultaty prac badawczych M. Görtemakera i Ch. Safferlinga są prezentowane w Niemczech, także w formie doskonałej pod względem faktografii i komentarza wystawy Rosenburg - Federalne Ministerstwo Sprawiedliwości Niemiec $w$ cieniu narodowosocjalistycznej przeszłości. W towarzyszącym ekspozycji przewodniku napisano na wstępie: „Ustalenia zawarte w opracowaniu Akta Rosenburg są równie przerażające, co zawstydzające"7.

Wspomniani autorzy ukazali w swoim wybitnym opracowaniu historyczno-prawnym, że utworzone w 1949 roku niemieckie Ministerstwo Sprawiedliwości opierało się na strukturze Justizministerium III Rzeszy, przy czym część pracowników nowego urzędu pełniła swe obowiązki jeszcze przed 1933 rokiem, a wiele osób miało za sobą kariery w narodowosocjalistycznym wymiarze sprawiedliwości ${ }^{8}$. Przez kilkanaście lat ponad 50\% kierowniczych stanowisk w wydziałach i referatach Ministerstwa Sprawiedliwości Republiki Federalnej Niemiec, obsadzonych w drodze powołania, zajmowali byli członkowie NSDAP lub SA, a w niektórych ministerialnych jednostkach organizacyjnych stanowili oni $70 \%$ kadry. Byli wśród nich również cieszący się uznaniem po wojnie komentatorzy prawa. Jednak, jak piszą Görtemaker i Safferling:

Ważniejszy od przynależności do NSDAP lub SA był fakt, że wielu pełniących funkcje kierownicze przed 1945 r. uczestniczyło, w ministerstwie narodowosocjalistycznego państwa, bezpośrednio w realizacji «woli Führera» [Führerwille]. Natomiast ,inni przez swoją działalność w sądownictwie, w tym w sądach specjalnych [Sondergerichte] III Rzeszy, a także, w sądach na «terenach okupowanych», jak również w sądownictwie wojskowym, ponosili ciężką osobistą winę za wdrażanie i stosowanie zbrodniczych ustaw, przygotowanych w Reichsjustizministerium ${ }^{9}$.

Lektura dzieł obu wspomnianych badaczy inspiruje do rekonstrukcji zdarzeń w systemie prawa i sądownictwa, w wyniku których juryści stali się wykonawcami woli Führera, a następnie przedstawienia jako przykładów wybranych wyroków wydanych przez Sondergericht Breslau. Celem poniższego wywodu jest zatem ukazanie w koniecznym skrócie procesu zanikania sprawiedliwościowego pojmowania kary w sędziowskich umysłach, a także odrzucenia przez niemieckich prawników elementarnych zasad prawa karnego — nullum crimen sine lege,

${ }^{6}$ M. Görtemaker, Ch. Safferling, Die Akte Rosenburg. Das Bundesministerium der Justiz und die NS-Zeit, München 2016, s. 588.

7 Ch. Lambrecht, [w:] Rosenburg - Federalne Ministerstwo Sprawiedliwości Niemiec w cieniu narodowosocjalistycznej przeszłości, przeł. M. Bainczyk, Kraków 2019, s. 2. Polska wersja wystawy, przygotowana wspólnie przez Instytut Zachodni im. Zygmunta Wojciechowskiego i Federalne Ministerstwo Sprawiedliwości i Ochrony Konsumentów Republiki Federalnej Niemiec, od 6 listopada 2019 roku była prezentowana na kampusie Krakowskiej Akademii im. Andrzeja Frycza Modrzewskiego, zaś od 21 stycznia 2020 roku w Urzędzie Marszałkowskim Województwa Wielkopolskiego w Poznaniu.

${ }^{8}$ M. Görtemaker, Ch. Safferling, op. cit., s. 451-452.

9 Ibidem, s. 452. 
nulla poena sine lege - i przyjęcia „zdrowego poczucia narodowego” za główną wytyczną w procedurze wydawania wyroków. Zbrodnicze następstwa tego zjawiska są widoczne na przykładzie wyroków skazujących na kary śmierci polskich robotników przymusowych, którzy, jako oskarżeni o ,antyniemieckie nastawienie", stanęli przed sądem specjalnym we Wrocławiu ${ }^{10}$.

\section{Narodowosocjalistyczne prawo karne}

2.1 .

W 1932 roku Hitler zdefiniował zadanie wymiaru sprawiedliwości jako polegające „W narodowosocjalistycznym państwie, w powstającej [w nim - W.K.] wspólnocie życia na ochronie naszego narodu przed destrukcyjnymi, a przez to szkodzącymi i zagrażającymi tej wspólnocie, zjawiskami"11.

Odejście od zasad prawa, na których opierał się kodeks karny z 1871 roku, uzasadniano hasłem głoszącym, że ,prawem jest to, co służy narodowi (Recht ist, was dem Volke nützt)". Program Narodowosocjalistycznej Niemieckiej Partii Robotników (Nationalsozialistische Deutsche Arbeiterpartei, dalej: NSDAP) głosił: „Żądamy zastąpienia prawa rzymskiego, służącego materialistycznemu porządkowi światowemu, prawem niemieckiej wspólnoty [ein deutches Gemeinrecht]" ${ }^{12}$.

Przejęcie przez nazistów rządów, którego początkiem było mianowanie 30 stycznia 1933 roku Hitlera kanclerzem Rzeszy, zainicjowało proces ścisłej centralizacji władzy państwowej i odrzucenia reguł trójpodziału, zastąpionych zasadą wodzostwa (Führerprinzip). Nie oznaczało to likwidacji trzech pionowych struktur władzy, lecz zbieg ich szczytów w osobie Führera, który już w Mein Kampf ogłosił, że demokratycznie wybrane władze Republiki Weimarskiej to „kanalie, które wyprzedały cały kraj”, a jej „rząd jest sam zdrajcą kraju, wolnym od wszelkiej kary", i zapowiadał utworzenie trybunału narodowego. Ogłosił także, że pewnego dnia „objawi się uczciwy idealista"13.

Narodowosocjalistyczna ,prostacka propaganda” — jak to określił Holger Schlüter - okazała się skuteczna, bowiem ulegli jej także prawnicy sądowi, którzy należeli do zupełnie innych grup społecznych niż szeregowi członkowie

10 Trzy wyroki wydane przez Sondergericht Breslau zanalizował, szczegółowo omawiając stany faktyczne i zamieszczając cytaty z uzasadnień, W. Lemiesz, Paragraf i zbrodnia, Warszawa 1963, s. 132 n.

11 E. Ritter, Justiz und innere Verwaltung, [w:] Enzyklopädie des Nationalsozialismus, red. H. Benz, H. Graml, H. Weiß, München 1997, s. 94.

$12 \mathrm{~W}$ realiach panowania NSDAP jej program był umieszczany na początku komentarza do Kodeksu karnego dla praktyków, co miało legitymować pod względem ideologicznym zawartą w nim wykładnię przepisów. Zob. A. Dalcke, E. Fuhrmann, K. Krug, K. Schäfer, Strafrecht und Strafverfahren, Berlin-München 1940, s. 1-4.

13 A. Hitler, Mein Kampf. Zwei Bände in Einem Band, München 1944, s. 610. 
NSDAP. Niemiecki badacz zaznaczył jednocześnie, że nie istniał otwarty ruch oporu wobec tworzącej się samowładzy Hitlera i jego partii, w szczególności ze strony narodowych elit ${ }^{14}$. Uważa się, że główną spośród wielu przyczyn upadku Republiki Weimarskiej była jej niezdolność do zintegrowania elitarnych grup społecznych i dostatecznie dużych części społeczeństwa z systemem parlamentarnym, co spowodowało, że nie powstała w nim ani świadomość republikańska, ani trwałe przywiązanie do demokracji ${ }^{15}$. Nie ukształtowały się zatem siły zdolne do skutecznego przeciwstawienia się likwidacji republiki.

\section{2 .}

Niemieccy prawnicy nie tylko zachowali bierność, lecz w oficjalnych oświadczeniach manifestacyjnie poparli proces tworzenia stanu państwowego, który zastąpił Konstytucję weimarską. Powołując się na art. 48 tej Konstytucji, 28 lutego 1933 roku — dzień po pożarze Reichstagu - wydano rozporządzenie Prezydenta Rzeszy „o ochronie narodu i państwa” (Reichstagsbrandverordnung ${ }^{16}$ ), z oficjalnym uzasadnieniem „konieczności obrony przed zagrażającymi państwu komunistycznymi aktami przemocy", które de iure et facto pozbawiało mocy wszystkie konstytucyjne postanowienia o prawach podstawowych: prawo do wolności osobistej i przekonań, wolność prasy ${ }^{17}$, stowarzyszeń i zgromadzeń, tajemnicę korespondencji, a także nietykalność miru domowego. Rozporządzenie to wprowadziło równocześnie karę śmierci za zdradę główną i podpalenia, a także niepodlegający kontroli policyjny areszt ochronny (Schutzhaft), polegający na zesłaniu do obozu koncentracyjnego. Dla wszystkich, a zwłaszcza prawników, musiało być oczywiste, że rozporządzenie to było przygotowywane przed podpaleniem Reichstagu, a jego ogłoszenie oznaczało w istocie wprowadzenie stanu wyjątkowego, zapewniającego narodowym socjalistom trwałą wszechwładzę.

${ }^{14}$ H. Schlüter, ,, ... für die Menschlichkeit im Strafmaß bekannt... ”. Das Sondergericht Litzmannstadt und sein Vorsitzender Richter, Recklinghausen 2005, s. 27.

15 R. Pommerin, Machtergreifung, [w:] Enzyklopädie des Nationalsozialismus, red. H. Benz, H. Graml, H. Weiß, München 1997, s. 577.

16 Verordnung zum Schutze von Volk und Staat, Reichsgesetzblatt (RGB1.) 1933 I, S. 83.

17 Już pierwotny program NSDAP (zaprezentowany przez Hitlera 24 lutego 1920 roku w Monachium) głosił w punkcie 23: „Żądamy prawnej walki przeciwko politycznemu kłamstwu i jego rozpowszechnianiu przez prasę. Żeby stworzyć niemiecką prasę żądamy, żeby: a) wszyscy kierownicy i współpracownicy pism, które ukazują się w języku niemieckim musieli być członkami narodu [Volksgenossen]; b) nieniemieckie gazety muszą mieć wyraźne zezwolenie państwa na ukazywanie się. Nie mogą one być drukowane w języku niemieckim; c) wszelki udział finansowy w niemieckich gazetach lub wpływanie na nie przez nie-Niemców [Nicht-Deutsche] będzie ustawowo zabroniony, a karą będzie zamykanie przedsiębiorstw prasowych i natychmiastowe wydalanie uczestniczących w nich nie-Niemców z Rzeszy. Gazety, które występują przeciwko woli powszechnej, są zakazane. Żądamy prawnej walki z kierunkiem w sztuce i literaturze, który ma osłabiający wpływ na nasze życie narodowe, i zamknięcia organizacji, które wykraczają przeciwko powyższym żądaniom". Programm der NSDAP, [w:] A. Dalcke, E. Fuhrmann, K. Krug, K. Schäfer, op. cit., s. 1. 
Zagraniczna praca $\mathrm{w}$ alarmistycznym tonie donosiła o tych wydarzeniach i zmianach w niemieckim prawie, pytając, co może następnie wydarzyć się w rządzonym przez nazistów kraju. H. Schlüter zauważył, że wielu szeregowych członków NSDAP i jej wodzowie, w tym Hitler i Goebbels, byli od dawna znani prawnikom jako uczestnicy procesów — w roli oskarżonych — przed sądami Republiki. Prokuratorzy i sędziowie, wiedząc, kim są przywódcy tej partii, musieli być świadomi, że w nowych realiach ich funkcje zostaną bezwzględnie wykorzystane przez narodowych socjalistów, w tym także w celu drakońskiego karania wszystkich ludzi, którzy zostaną uznani za „zdrajców i knujących przeciwko rządowi”. Dlatego Schlüter trafnie komentuje — z wyraźną ironią — zdumiewająco zgodną postawę jurystów: „W tych warunkach oficjalne stanowiska organizacji prawniczych w odniesieniu do nowego rządu były zaskakująco pozytywne [überraschend positiv]" ${ }^{\prime 18}$. Niemiecki badacz cytuje również opublikowane 19 marca 1933 roku (trzy tygodnie po ogłoszeniu unieważniającego prawa podstawowe Reichstagsbrandverordnung) odrzucające wszelką krytykę ze strony zaniepokojonej zagranicy stanowisko Niemieckiego Związku Sędziów i Prokuratorów, programowo - według deklaracji - troszczącego się o sędziowską niezawisłość:

Niemieckie prawo obowiązuje w niemieckich Landach! Niemiecki sędzia był od dawna świadomy swej narodowości i odpowiedzialności. Zawsze wypełniało go poczucie społeczne i stosował on prawo zgodnie z ustawą i sumieniem. I tak musi pozostać! Wielkie dzieło odbudowy państwa wymagać będzie oddania niemieckiemu narodowi poczucia bezwzględnej do niego przynależności. Niemiecki związek sędziów deklaruje pełne zaufanie wobec nowego rządu ${ }^{19}$.

Tak samo buńczuczne (opatrzone wykrzyknikiem) odrzucenie wszelkich zewnętrznych ocen zmian prawa - „Niemieckie prawo obowiązuje samodzielnie w niemieckich Landach!" — zawarte zostało w wydanym następnego dnia (20 marca 1933 roku) oświadczeniu pruskiego stowarzyszenia sędziów i prokuratorów. Zapewniono w nim, że jego członkowie podejmą „gorące starania”, aby odbudowa niemieckiego prawa i jego stosowanie służyły niemieckiej wspólnocie narodowej, a sprawą ich „czci i godności [die Ehre und die Würde]” jest „podbudowanie i wspieranie nowego państwa stworzonego przez narodową rewolucję". Wszystko to po to, żeby nastąpiło „uzdrowienie całego naszego życia publicznego, a przez to ponowne wyniesienie Niemiec" 20 .

18 H. Schlüter, op. cit., s. 27.

19 Cyt. za: H. Schlüter, op. cit., s. 28.

20 Cytowane oświadczenia zamieściła na pierwszej stronie zeszytu 7 (z datą 1 kwietnia 1933 roku) „Deutsche Juristen-Zeitung” (s. 453-454), dalej następowały identyczne w treści oświadczenia zarządów niemieckiego stowarzyszenia adwokatów (s. 454-455) i notariuszy (s. 455). Nie można nie zauważyć, że to wydanie „Deutsche Juristen-Zeitung” ukazało się z profetyczną ,primaaprilisową" datą: den 1. April 1933. 


\section{3 .}

Wydanym 21 marca 1933 roku, przy poparciu prawników, rozporządzeniem powołano sądy specjalne w okręgu każdego wyższego sądu krajowego, których zadaniem było orzekanie w sprawach przestępstw politycznych. W trzyosobowych składach tych sądów zasiadali zawodowi sędziowie, cieszący się politycznym zaufaniem i dający rękojmię spełnienia postawionych przed nimi celów. W kolejnych latach kompetencje sądów specjalnych rozszerzono o wszystkie sprawy, w przypadku których prokuratorzy uznali, że jest to uzasadnione „ciężarem lub zarzucalnością czynu" oskarżonego. Sądy te w założeniu miały procedować szybko, w jednoinstancyjnym postępowaniu, na podstawie uproszczonej procedury, ograniczającej prawa oskarżonego, któremu nie przysługiwało odwołanie od skazującego go wyroku.

Prawem materialnym, na podstawie którego orzekały sądy specjalne, były początkowo przepisy Reichstagsbrandverordnung i zarządzenia prezydenta Rzeszy z 21 marca 1933 roku, ,dla obrony przed zdradzieckimi zamachami na rząd odnowy narodowej”, grożącego karą ciężkiego więzienia za rozpowszechnianie „nieprawdziwych twierdzeń" o państwie i rządzie. Uchwalona ponad rok później (20 grudnia 1934 roku), ustawa przeciwko zdradzieckim [heimtückische] zamachom na Państwo i Partię oraz ochronie uniformów partyjnych" [Heimtückegeset] ${ }^{21}$ objęła taką samą ochroną organy i przywódców zarówno państwa, jak i partii. Karalne stały się wszelkie „niepubliczne złośliwe wypowiedzi” mogące zaszkodzić wizerunkowi rządu lub NSDAP, przy czym dla ich ujawnienia zapewniono legalność każdej denuncjacji. W praktyce stosowania tej ustawy — jak się komentuje - uwidoczniła się we wszystkich warstwach społeczeństwa wcześniej „utajona gotowość do donosicielstwa [die latente Denunziationsbereitschaft]"22.

Posługując się stale hasłem ,wspólnoty narodowej” (Volksgemeinschaft), w której interesie jest stabilizacja sytemu władzy i utrzymanie porządku wewnętrznego, stworzono zatem sprawnie działający mechanizm likwidujący w zarodku, choćby tylko werbalne, formy sprzeciwu ze strony wszystkich nieprzekonanych do narodowego socjalizmu, a nawet plotkarskie wypowiedzi o Hitlerze i prominentach ${ }^{23}$.

\section{4 .}

Proces przejmowania przez nazistów władzy został formalnie zwieńczony 24 marca 1933 roku, bowiem od tego dnia obowiązywała ustawa o specjalnych pełnomocnictwach dla rządu Rzeszy, a w praktyce Hitlera jako kanclerza, do

${ }^{21}$ RGBl. 1933 I, S. 1269.

22 N. Hasse, Denunziantentum, [w:] Enzyklopädie des Nationalsozialismus, red. H. Benz, H. Graml, H. Weiß, München 1997, s. 416.

23 Przykład skazania na podstawie Heimtückegesetz zob. W. Kulesza, „Polskie obchody” rocznicy urodzin Hitlera w świetle prawa karnego III Rzeszy, Republiki Federalnej Niemiec i Pol$s k i$, „Państwo i Prawo” 2018, nr 7, s. 7-8. 
wydawania ustaw bez zgody Reichstagu, łącznie z ustawą budżetową, i zawierania porozumień z innymi państwami (Ermächtigungsgesetz) ${ }^{24}$.

Ustawa ta miała zapewnić „uchylenie stanu opresji Narodu i Rzeszy” (Das Gesetz zur Behebung der Not von Volk und Reich) i rzekomo uchwalono ją z ,inicjatywy Reichstagu"25. O dacie zainicjowania przez parlament tego aktu wspominała „Deutsche Juristen-Zeitung” w komentarzu redakcyjnym, rozpoczynającym się poetyckimi słowami: „21 marca 1933, dzień przebudzenia wiosny, był równocześnie przebudzeniem Niemieckiego Narodu. Po długiej zimowej nocy mogą Niemcy wierzyć, że nadchodzi odbudowa" 26 . W tym samym numerze tej prawniczej gazety „Professor Dr. Carl Schmitt” komentował pełnomocnictwa dla kanclerza i jego rządu: „Dziś nie chodzi tylko o uprawnienie do przełamywania konstytucyjnych postanowień $\mathrm{w}$ pojedynczych przypadkach, lecz o wiele dalej idace prawo do wydawania nowych ustaw konstytucyjnych, w miejsce dotychczasowego ustawodawstwa konstytucyjnego". Następnie dodawat: „Nowa ustawa jest ponadto wyrazem zwycięstwa narodowej Rewolucji [wyr. oryg. - W.K.]"27.

Od 1933 roku do początku wojny Reichstag uchwalił przy zachowaniu parlamentarnej procedury dziewięć ustaw, natomiast rząd Rzeszy wydał 4500 ustaw (Regierungsgesetze), a Hitler jeszcze większą liczbę niepublikowanych rozkazów (Führererlasse) i zarządzeń z mocą ustawy.

Stworzony przez NSDAP po przejęciu władzy stan rzeczy stał się nieodwracalny. Karol Jońca w swym studium narodowosocjalistycznego prawa karnego wskazywał, że stosunek partii Hitlera wobec „systemu weimarskiego” określił w swych przemówieniach Reinhard Heydrich: ,,przyjęliśmy jego reguły gry [...] i środkami konstytucyjnymi, w drodze legalnej, zniszczyliśmy system, który zresztą dojrzał do tego, by w każdej chwili podać się do dymisji” ${ }^{28}$. W nowych warunkach „NSDAP

${ }^{24}$ W wyborach z 5 marca 1933 roku NSDAP uzyskała 43,9\% głosów i dodając do tego 8\% zdobyte przez nacjonalistyczną Niemiecką Narodową Partię Ludową (Deutschnationale Vokspartei - DNVP), rząd koalicyjny dysponował większością parlamentarną na poziomie $51,9 \%$, lecz pomimo to Hitler wystąpił o uchwalenie „ustawy o pełnomocnictwach” (Ermächtigungsgesetz), która wyłączała Reichstag ze struktury władzy (początkowo na okres pięciu lat). Uchwalenie aktu zawierającego sprzeczne z konstytucją postanowienia wymagało pozyskania dla niego $2 / 3$ posłów do Reichstagu, co też nastąpiło 23 marca 1933 roku za sprawą specyficznej formy nacisku, jaką były obecność uzbrojonych członków SA i SS na sali posiedzeń plenarnych oraz ogłoszenie, że w ten sposób dokonuje się „legalnej rewolucji”. Zob. H. Auerbach, Ermächtigungsgesetz, [w:] Enzyklopädie des Nationalsozialismus, red. H. Benz, H. Graml, H. Weiß, München 1997, s. 448-449. Jak oficjalnie podano, Reichstag przyjął Ermächtigungsgesetz 441 głosami „za” wobec 94 ,,przeciw”, co stanowiło „przekroczenie większości wymaganej dla zmiany konstytucji” i spowodowało, że choć parlament nadal istniał, to „na jego miejsce wstąpił rząd Rzeszy”. Zob. „Deutsche JuristenZeitung“" 1933 , nr 7, s. 481.

25 VIII kadencji, druk nr 6 z 21 marca 1933 roku.

26 „Deutsche Juristen-Zeitung“ 1933, nr 7, s. 453.

27 C. Schmitt, Das Gesetz zur Behebung der Not von Volk und Reich, „Deutsche Juristen-Zeitung" 1933, nr 7, s. 456.

28 K. Jońca, Koncepcje narodowosocjalistycznego prawa w Trzeciej Rzeszy, „Studia nad Faszyzmem i Zbrodniami Hitlerowskimi” 3, 1977, s. 72. 
— a nie państwo — powinna stać się kierowniczym zakonem narodu"29. Oznaczało to, że państwo stawało się środkiem do realizacji narodowego socjalizmu, a program partii, jak określił to Hans Frank, „był konstytucją Niemiec”30.

\section{5 .}

Po dwóch tygodniach od przechwycenia władzy rząd Rzeszy wydał, wykorzystując uprawnienia przewidziane w Ermächtigungsgesetz, rozporządzenie „ustawa o odbudowie zawodowego urzędnictwa" (Berufsbeamtengesetz) ${ }^{31}$, którego tytuł sugerował, że w okresie istnienia demokratycznej Republiki Weimarskiej nastąpił upadek zasad, jakimi powinni kierować się urzędnicy państwowi, którzy rzekomo poświęcili je dla realizacji swych politycznych interesów, toteż powinni zostać objęci mającą trwać pięć miesięcy akcją wymiany $\mathrm{kadr}^{32}$. Akt ten wskazywał cztery grupy urzędników, w tym sędziów, podlegających zwolnieniu ze służby:

— osoby powołane na stanowiska po 9 listopada $1918 \mathrm{roku}$, lecz niemające odpowiedniego wykształcenia lub innych kwalifikacji, a także prowadzące wcześniej działalność w Komunistycznej Partii Niemiec (lub dla niej) bądź aktywność marksistowską, w tym również socjaldemokratyczną;

—Żydzi, określeni jako „nie-Aryjczycy”, którzy zostali przeniesieni w stan spoczynku;

- wszyscy urzędnicy, którzy w swojej dotychczasowej politycznej działalności nie dawali gwarancji bezwzględnego i każdorazowego wstawienia się za narodowym państwem (w trzecim zarządzeniu o odtworzeniu urzędnictwa sprecyzowano, że zwolniony zostanie „każdy urzędnik, jeśli słowem lub pismem albo w inny sposób występował nienawistnie przeciwko ruchowi narodowosocjalistycznemu, obrażał jego Führera lub nadużywał swego służbowego stanowiska dla prześladowania narodowo nastawionych urzędników") ${ }^{33}$;

— inni pracownicy instytucji państwowych, przenoszeni w stan spoczynku ze względu na potrzebę usprawnienia administracji lub w interesie służby, także „jeżeli nie są oni niezdolni do służby”.

Pomimo całkowitej dowolności w posługiwaniu się tymi przepisami, pozwalającymi degradować urzędników na najniższe stanowiska i zmuszać ich do składania wniosków o zwolnienie, zamierzenia organizatorów akcji wymiany kadr — statystycznie rzecz biorąc — nie zostały zrealizowane, gdyż 30000 pozbawionych pracy urzędników stanowiło około $2 \%$ wszystkich będących w służbie publicznej.

29 W. Stuckart, Neubau des Reichs, „Deutsches Recht” 1939, nr 18, cyt. za: K. Jońca, op. cit., s. 72 .

30 K. Jońca, op. cit., s. 73.

31 Gesetz zur Wiederherstellung des Berufsbeamtentums, RGB1. 1933 I, S. 175 ff.

32 Reichsgesetzblat I, S. 175. Termin weryfikacji urzędników przedłużano następnie aż do 1937 roku.

33 Cyt. za: H. Schlüter, op. cit., s. 35. 
Jednakże równocześnie trzeba podkreślić, że ustawa ta wpływała na motywacje tych wszystkich, którzy masowo wstępowali od 1933 roku w szeregi NSDAP, kierując się oportunizmem i myślą o zabezpieczeniu swej własnej kariery, a władze Rzeszy nie zawiodły tych nadziei wobec lojalnych i posłusznych członków partii ${ }^{34}$. Roland Freisler (1893-1945), podsekretarz stanu w ministerstwie sprawiedliwości, głosił hasło, w myśl którego celem władzy ma być „,nie reforma wymiaru sprawiedliwości, ale reforma prawników!”35. Zastanawiając się nad tym, czy wśród motywacji jurystów do wstępowania w szeregi partii Hitlera był również strach, H. Schlüter zaznacza, że w tym okresie nie było przymusu formalnego przyłączenia się do ruchu narodowosocjalistycznego, i zauważa: ,Żaden prawnik nie utracił swego stanowiska $\mathrm{z}$ tego powodu, że nie był towarzyszem partyjnym”. Dopiero od 1939 roku członkostwo w NSDAP stało się warunkiem powołania nowych sędziów, a od 1942 roku było ono wymogiem w przypadku awansów na wyższe stanowiska. Otto Thierack (1889-1946), który w 1942 roku został ministrem sprawiedliwości Rzeszy, zwolnił wielu sędziów i prokuratorów, w tym jedenastu prezesów wyższych sądów krajowych i czterech prokuratorów generalnych, z powodu „niearyjskiego pochodzenia”, „niedostatecznej współpracy z partią”, „braku członkostwa w NSDAP” i ,zachowania sprzyjającego Żydom i Polakom” ${ }^{36}$.

\section{6 .}

Możliwość jakiegokolwiek zorganizowanego sprzeciwu wobec NSDAP została wykluczona ustawą przeciwko tworzeniu nowych partii z 14 lipca 1933 roku $^{37}$, zawierającą dwa paragrafy:

$\S 1$. W Niemczech istnieje jako jedyna partia polityczna Narodowosocjalistyczna Niemiecka Partia Pracujących [die Nationalsozialistische Deutsche Arbeiterpartei]. § 2. Kto podejmuje organizacyjne współdziałanie, żeby [inną — W.K]) partię polityczną utrzymać lub nową partię zbudować, będzie karany ciężkim więzieniem [Zuchthaus] do trzech lat lub więzieniem [Gefängnis] od sześciu miesięcy do trzech lat, o ile czyn nie jest zagrożony surowszą karą przez inne przepisy.

34 Artur Greiser, gauleiter tak zwanego Kraju Warty (Warthegau), stając przed Najwyższym Trybunałem Narodowym podczas procesu, który odbywał się w Poznaniu od 21 czerwca do 9 lipca 1946 roku, tak opowiadał o swym wstąpieniu do NSDAP (1930 rok): „Byłem zdania, że nędza socjalna, która panowała wówczas w Niemczech, będzie usunięta przez utworzenie rządu NSDAP”. O programie partii mówił: „Nie mogę dziś powiedzieć, czy poprzednio program ten czytałem, czy nie. Dla wyjaśnienia mogę podać, że na pewno 90 proc. Członków NSDAP programem się nie zajmowało”. W swym ostatnim słowie ten sprawca zbrodni przeciwko ludzkości przekonywał, że: „człowiek udaje się do tej partii i do tej organizacji, która daje mu pracę i chleb”. Zob. Proces Artura Greisera przed Najwyższym Trybunatem Narodowym, Warszawa 1946, s. 5, 221.

35 K. Jońca, op. cit., s. 84.

36 Pismo Ottona Thieracka z 20 października 1942 roku, cyt. za: D. Schenk, Poczta Polska w Gdańsku. Dzieje pewnego niemieckiego zabójstwa sądowego, przeł. W. Tycner, J. Tycner, Gdańsk 1999, s. 170.

37 RGB1. 1933 I, S. 479. 
7 września 1939 roku weszło w życie zarządzenie o nadzwyczajnych środkach przeciwko zagranicznym nadawcom radiowym (Rundfunkverordnung) ${ }^{38}$. $\S 1$ tego rozporządzenia stanowił: „Zamierzone słuchanie zagranicznego nadawcy [ausländischer Sender] jest zakazane. Zachowania sprzeczne będą karane ciężkim więzieniem [Zuchthaus]. W lekkich przypadkach [in leichten Fällen] może być zastosowane więzienie [Gefängnis]". Następny paragraf (2) głosił: „Kto zamierzenie rozpowszechnia wiadomości zagranicznego nadawcy, które mogą zagrażać sile oporu [Widerstandskraft] niemieckiego Narodu, będzie karany ciężkim więzieniem, a w szczególnie ciężkich przypadkach śmiercią [mit dem Tode]". Postępowania w sprawach o naruszenie zakazów ustanowionych w Rundfunkverordnung zostało zlecone sądom specjalnym, które miały już doświadczenie w karaniu na podstawie Heimtückegesetz z 1934 roku.

\section{7 .}

Na pierwszej stronie tygodnika „Juristische Wochenschrift” z 16 grudnia 1933 roku Carl Schmitt opublikował Nowe tezy przewodnie dla praktyki sadowej (Neue Leitsetze für die Rechtspraxis), rozpoczynające się od następującego stwierdzenia: „Niezawisłość sędziów opiera się na ich związaniu z ustawą państwa, które to prawo ma wypowiadać sędzia. Bez owego związania niezawisłość sędziowska staje się polityczną samowolą”. Dalej ,jurysta Hitlera” przestrzegał, że „decyzja czy dana okoliczność nie jest polityczna stanowi zawsze decyzję polityczną". Kolejna teza Schmitta głosiła, że „dla używania i posługiwania się klauzulami generalnymi przez sędziów, prokuratorów i nauczających prawa miarodajne są bezpośrednio i wyłącznie zasady narodowego socjalizmu”. Na końcu autor tekstu ogłosił, że: „narodowosocjalistyczne państwo jest państwem sprawiedliwym [Der nationalsozialistische Staat ist ein gerechter Staat]"39.

Trzy miesiące później ten sam autor na łamach tego samego periodyku przedstawił w długim wywodzie tezy stanowiące przykład prawniczego kuglarstwa - pisał on bowiem, że ,zgodność z ustawowymi podstawami i porządkiem [Gesetzmäßigkeit und Ordnung], pod którymi rozumie się pojęcie państwa prawa, są na dobre zabezpieczone" ${ }^{40}$. Schmitt jednocześnie twierdził, że pojęcie „Rechtsstaat” jest historyczne wcześniejsze od terminu „narodowy socjalizm”, dlatego konstatował z naciskiem: „Nie określamy narodowego socjalizmu poprzedzającym go pojęciem państwa prawa, lecz odwrotnie, to państwo prawa [Rechtsstaat] pochodzi z narodowego socjalizmu" 41 .

38 Verordnung über außenordentliche Rundfunkmaßnahmen vom 1.09.1939, RGB1. I, S. 1683.

39 C. Schmitt, Neue Leitsetze für die Rechtspraxis, ,Juristische Wochenschrift“" 1933, nr 50, s. 2793.

40 C. Schmitt, Nationalsozialismus und Rechtstaat, ,Juristische Wochenschrift“ 1934, nr 12/13, 24. und 31. März 1934, s. 718.

41 Ibidem, s. 716. 


\section{8 .}

Działający od 1879 roku jako najwyższa instancja sądowa w sprawach cywilnych i karnych Sąd Najwyższy Rzeszy (Reichsgericht), z siedzibą w Lipsku, utracił w 1933 roku swe kompetencje rewizyjne odnośnie do orzeczeń mających za przedmiot przestępstwa polityczne, ponieważ od wyroków ferowanych przez sądy specjalne, powołane $\mathrm{w}$ tym czasie do orzekania $\mathrm{w}$ tej kategorii spraw, nie przysługiwały żadne środki odwoławcze. Ustawą z 24 kwietnia 1934 roku o utworzeniu Trybunału Narodowego (Volksgerichtshof) w Berlinie przekazano sprawy zbrodni zdrady głównej i zdrady kraju (Hoch- und Landesverrat) z kompetencji Reichsgerichtu do właściwości orzeczniczej nowego trybunału. W piśmiennictwie wskazuje się, że bezpośrednią przyczyną powołania tej instytucji sądowniczej było oburzenie narodowosocjalistycznej władzy na wyrok wydany 23 grudnia 1933 roku przez Sąd Najwyższy Rzeszy w procesie pięciu oskarżonych o podpalenie Reichstagu. Orzeczenie to uznano za niezadowalające, bowiem nie zostało wydane ,według poczucia prawnego narodu [nach dem Rechtsempfinden des Volkes]"42.

Nowo powołany Volksgerichtshof orzekał w pięcioosobowym składzie, złożonym z dwóch sędziów zawodowych i trzech ławników, przedstawicieli policji, NSDAP i wojska - wszyscy byli powoływani przez Hitlera na wniosek ministra sprawiedliwości. W 1935 roku sądy zostały w pełni podporządkowane pod względem organizacyjnym Ministerstwu Sprawiedliwości Rzeszy, które decydowało o podziale zadań i powołaniach sędziowskich, warunkowanych wcześniejszą akceptacją danego kandydata przez krajowe kierownictwo NSDAP ${ }^{43}$.

42 Zgodnie z żądaniem oskarżenia Reichsgericht skazał na karę śmierci aresztowanego 27 lutego 1933 roku na miejscu pożaru Holendra Marinusa van der Lubbego, naginając przy tym prawo i łamiąc zasadę nulla poena sine lege, ponieważ obowiązujące w czasie popełnienia przez oskarżonego czynu prawo nie przewidywało w danym przypadku takiej kary, groziło jedynie terminowym więzieniem. Dopiero w wydanym następnego dnia po pożarze Reichstagsbrandverordnung ustanowiono karanie śmiercią między innymi za zdradę główną i wzniecenie pożaru. O skazaniu domniemanego sprawcy van der Lubbego na karę śmierci zdecydowały także opinie uniwersyteckich profesorów (Johannesa Naglera z Wrocławia, Hellmutha von der Webera z Jeny i Friedricha Öttkera z Würzburga), którzy zgodnie stwierdzili, że zasada nulla poena sine lege nie powinna obowiązywać w sposób nieograniczony, por. K. Jońca, op. cit., s. 79. Czterech współoskarżonych z van der Lubbem, których prawo do obrony było respektowane w trakcie procesu, zostało uniewinnionych z braku wystarczających dowodów na ich udział w „,bolszewickim akcie terroru”, jak określała to ówczesna propaganda; postanowienie to uznano za „ciężki błąd” powodujący „,zdziwienie i rozczarowanie" wśród szerokich rzesz Niemców, zob. F. Ryszka, Państwo stanu wyjątkowego. Rzecz o systemie państwa i prawa Trzeciej Rzeszy, Wrocław 1985, s. 392. Szczegółowe badania dotyczące przyczyn ustanowienia Volksgerichtshofu prowadzą do wniosku, że ,istotniejszą [przyczyną — red.] aniżeli zawiedzione zaufanie do sędziów Reichsgerichtu była potrzeba zagwarantowania wydolnego i szybkiego postępowania, realizującego polityczne prawo karne”; zob. K. Marxen, H. Schlüter, Terror und „Normalität”. Urteile des nationalsozialistischen Volksgerichtschof: Eine Dokumentation, Recklinghausen 2004, s. 10.

43 Szerzej zob. W. Kulesza, Crimen laesae iustitiae..., s. 29 n. 


\section{9 .}

Na uniwersytetach do roku 1939 usunięto z przyczyn politycznych $45 \%$ profesorów ordynaryjnych kierujących katedrami, a 60\% katedr nauk prawnych zostało obsadzonych nowymi profesorami. Połowa elit akademickich zrobiła kariery w III Rzeszy, a druga połowa prawie bez wyjątku była silnie konserwatywna i zachowywała się oportunistycznie, dopasowując się do zmieniających się warunków ${ }^{44}$.

Ewentualne wyrazy dezaprobaty $\mathrm{z}$ ich strony polegały na przemilczeniu dokonywanych przez narodowych socjalistów zmian w prawie. W publikacjach natomiast były one otwarcie popierane przez prawników, co znalazło wyraz na łamach czasopisma „Das Recht”, gdzie głoszono, że ustanowione w 1933 roku prawo zostało sformułowane „, jedynie słusznego punku widzenia: ustawy są rozkazami narodu, powinny odpowiadać poczuciu prawnemu narodu, spełniać roszczenia jego członków i przez to służyć narodowej wspólnocie" 45 . Trzeba tutaj zaznaczyć, że popularny „Juristische Wochenschrift” obwieścił na pierwszej stronie zeszytu nr 31 (z 31 sierpnia 1933 roku), że jako organ Związku Narodowosocjalistycznych Niemieckich Prawników będzie zamieszczał tylko artykuły, których autorzy są Aryjczykami [die Arier sind], a książki niearyjczyków lub wydane przez niearyjskie wydawnictwa nie będą omawiane i nie będzie żadnych informacji na ich temat.

\subsection{0 .}

Doskonałą analizę i syntezę ideologii narodowosocjalistycznego prawa karnego przeprowadził Kai Ambos, ukazując rolę jurystów w sformułowaniu hasła głoszącego, że „najpierwszym niemieckim dziedzicznym dobrem jest obowiązek wierności wobec Führera, Narodu i Państwa"46. Pojęcie „narodu niemieckiego” oparte zostało na założeniu, że pełnoprawnym jego członkiem (Rechtsgenossen) jest ten, kto należy do wspólnoty krwi germańskich Aryjczyków (Volksgenossen), z zastrzeżeniem, że wobec narodu i Führera ma on obowiązki, nie zaś prawa ${ }^{47}$.

Wyprowadzona $\mathrm{z}$ tych założeń idea wspólnoty narodowej (Volksgemeinschaft) dotyczyła również sędziów, ponieważ ich pierwszą powinnością stało się służenie Hitlerowi. Zatem działając $w$ imieniu państwa, nie byli oni niezależni w możliwym wszak z istoty sędziowania ograniczaniu władczego państwowego karania, lecz sami - jako narodowosocjalistyczne osobowości przywódcze wykonywali funkcje, których celem było szersze, niż to wynikało z werbalnej treści przepisów karnych, wskazywanie i obciążanie zarzutami domniemanych

\footnotetext{
44 I. Müller, op. cit...., s. 237.

45 Cyt. za: H. Schlüter, op. cit., s. 28.

46 K. Ambos, Nationalsozialistisches Strafrecht, Baden-Baden 2019, s. 32.

47 Ibidem, s. 35.
} 
sprawców czynów uznawanych za knowania przeciwko Führerowi i niemieckiemu narodowi ${ }^{48}$. Karanie samo w sobie stało się celem nadrzędnym, co znalazło wyraz w zastąpieniu zasady nulla poena sine lege hasłem nullum crimen sine poena $^{49}$. Oznaczało to, że żaden czyn uznany przez prokuratora i sędziego za zasługujący na ukaranie nie może pozostać bez kary wymierzonej w jego sprawcę.

Decydującą i wystarczającą racją karania stało się sędziowskie „zdrowe poczucie narodowe" jako samoistne źródło prawa. Przyjęto, że „sprawiedliwe jest to, czego sobie życzy niemiecki naród i co mu służy”, przy czym treść woli narodu — podkreślano - musi być „zdrowa”, to jest zgodna z określoną przez przywództwo NSDAP narodowosocjalistyczną ideą prawa i z oczekiwaniami oraz życzeniami Führera ${ }^{50}$.

Generalnie wskazywano, że głównym celem nowego niemieckiego prawa karnego jest utrzymanie połączonej węzłem krwi wspólnoty narodu niemieckiego, zdefiniowanej przez wierność, obowiązek, cześć i sprawiedliwą pokutę sprawców przestępstw za ich zachowania. Odrzucone zostało zatem odróżnienie poczucia moralnego od prawa stanowionego. Jak stwierdził Hans Frank: „w niemieckim myśleniu zachodzi jedność miedzy oceną moralną, poczuciem obowiązku i poczuciem prawa" 51 .

Profesor prawa karnego Edmund Mezger (1883-1962) dobitnie i zwięźle ogłosił: „Materialnie bezprawne zachowanie jest zachowaniem przeciwko niemieckiemu narodowosocjalistycznemu światopoglądowi" ${ }^{52}$. Nikt nie wyrażał tego światopoglądu w prawotwórstwie w pełniejszy sposób niż sam Führer, dlatego uznano, że „,centralną instancją stanowienia norm prawa był Adolf Hitler" ${ }^{\prime 53}$. Wyrażana, a niekiedy tylko domniemana „«wola Führera» [Führerwille] była dla wszystkich państwowych instancji najwyższym nakazem" $" 54$.

Professor ordinarius prawa karnego Georg Dahm (1904-1963), twórca szkoły prawa karnego w Kilonii (Kieler Schule), ogłosił w 1936 roku., że: „Sędziom nie przysługuje żadne prawo badania [kein Prüfungsrecht] decyzji Führera noszących szaty ustawy lub rozporządzenia" ${ }^{\text {. }}$.

Sędziów instruowano, że „ustawa jest wyrazem woli kierownictwa państwa,

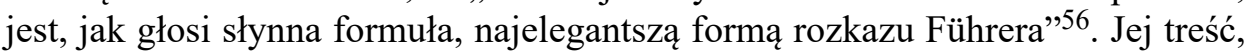
jako nadana przez Hitlera, będącego władzą ustawodawczą, nie podlega badaniu

48 Ibidem, s. 35.

49 Ibidem, s. 36.

50 Ibidem, s. 40.

51 Ibidem, s. 41, przypis 137.

52 „Materiell rechtswidriges Handeln ist Handel gegen die deutsche nationalsozialistische Weltanschauung", cyt. za: I. Müller, op. cit., s. 84.

53 B. Rüthers, op. cit., s. 122.

54 Ibidem, s. 122.

55 Cyt. za: E. Klee, Das Personenlexikon zum Dritten Reich. Wer war was vor und nach 1945?, Frankfurt am Main 2003, s. 100.

56 D. Schenk, op. cit., s. 198. 
przez reprezentujących wymiar sprawiedliwości sędziów, gdyż: „W końcu nie po to została zniesiona zasada trójpodziału władzy, żeby wprowadzać ją ponownie w życie na sali sądowej” ${ }^{57}$.

\subsection{1}

Pojęcie „zdrowego poczucia narodowego" wprowadzono do kodeksu karnego jako klauzulę generalną, mającą zastąpić ustawowe opisy podlegających karze czynów zabronionych. Podniesiono niemożność ujęcia w przepisach prawa wszystkich typów czynów zasługujących na ukaranie i dlatego - jak stwierdził profesor prawa karnego Heinrich Henkel — zachodzi potrzeba sformułowania wytycznych dla sędziów, które sprawią, że nie będzie dłużej głoszona zasada „,co nie jest zabronione, jest dozwolone [was nich verboten ist, ist erlaubt]", a zastąpi ją maksyma „co nie jest dozwolone, jest zabronione [was nicht erlaubt ist, ist verboten]" 58 .

Sędziom stworzono szerokie możliwości wykazania swej inicjatywy w decydowaniu, co jest zabronione, w drodze karania per analogiam iuris. W nowelizacji Strafgesetzbuchz z 28 czerwca 1935 roku przepisowi $§ 2$ nadano oznaczenie „§ 2a”, poprzedzając go paragrafem „2”, w którym sformułowano klauzulę generalną głoszącą, że karany będzie ten, kto popełnia czyn zabroniony opisany w ustawie lub zasługujący na ukaranie ,według myśli przewodniej ustawy karnej [nach dem Grundgedanken eines Strafgesetzes]" i ,według zdrowego poczucia narodowego [nach gesundem Volksempfinden]". W komentarzu wyjaśniano, że nowy przepis, „w interesie materialnej sprawiedliwości”, pozwala na odejście od wcześniej przyjętych zasad i karanie za czyn niezagrożony karą w ustawie, jeżeli przemawiają za tym podstawowa myśl karania i sędziowskie zdrowe poczucie narodowe. W ten sposób, podkreślano, „ustawa i prawo” (Gesetz und Recht) stały się źródłami prawa karania tej samej rangi ${ }^{59}$. „Ustawą” były przepisy ustanowione z jej mocą obowiązywania, natomiast jako "prawo” określone zostało wszystko to, co (choćby niezapisane) „służy niemieckiemu narodowi”. Celem karania przez sędziego, według jego poczucia „prawa”, stało się „zamykanie” przez wyroki skazujące niezamierzonych przez ustawodawcę „luk w ustawach” i objęcie karalnością tych zachowań podsądnych, które wprawdzie nie zostały ujęte jako czyny karalne w dotychczasowych ustawach, jednakże ,ustawodawca przypuszczalnie chciał, aby spotykały się z karą, ponieważ myślał o nich, gdy wydawał ustawy". Twierdzenie to powtarzano, podkreślając rozstrzelonym drukiem słowa „niezamierzone luki” (unbeabsichtigte Lücken), między innymi w popularnym podręczniku prawa karnego dla policji i żandarmerii, co sprawiło,

57 Ibidem, s. 198-199.

58 I. Müller, op. cit., s. 83.

59 A. Dalcke, K. Schäfer, [w:] A. Dalcke, E. Fuhrmann, K. Krug, K. Schäfer, Strafrecht und Strafverfahren, Berlin-München 1940, s. 8. 
że brak odpowiedniego przepisu w kodeksie karnym tym bardziej zobowiązywał do wykazania się ,zdrowym poczuciem narodowym” w praktyce ścigania czynów niezabronionych ustawowo ${ }^{60}$. Tak też thumaczono drugie zdanie przepisu $\S 2$, mówiące, że ,jeżeli do czynu nie znajduje bezpośrednio zastosowania żaden przepis ustawy, to czyn taki zostanie ukarany według ustawy, której myśl przewodnia najlepiej się do niego odnosi". Takie postępowanie sędziego zapewniało karanie czynu z powodu „zawartego w nim materialnego bezprawia”, choćby formalnie nie został on opisany jako przestępstwo. „Materialne bezprawie” zachowania rozpoznawali sami sędziowie, często ignorując całkowicie werbalne brzmienie przepisu prawa, powołując się na to, że ponad prawem pisanym stoi dobro narodu niemieckiego.

„Odformalizowana” została zatem treść przepisów karnych, uznanych jedynie za „wytyczne” dla karzących sędziów ${ }^{61}$. Posługując się tymi kategoriami, wnieśli oni swój własny wkład do bezprawia III Rzeszy — „bez ich aktywnego udziału pozostawałby nie urzeczywistniony projekt narodowosocjalistycznego prawa karnego"62.

Bernd Rüthers podsumowuje swoje studium, stwierdzając, że zmiana systemu politycznego w państwie ,produkuje wysoką koniunkturę dla prawa sędziowskiego (Richterrecht). Sądy zmieniają się z organów stosujących prawo (Rechtsanwendern) w organy ustawodawcze (Gesetzgebern). Zmieniają swą rolę służenia ustawom, stając się „"panami porządku prawnego» [Herren der Rechtsordnung] wszędzie tam, gdzie odstępują od ustaw, pozbawiają je znaczenia lub uzupełniają. Nauki prawne udzielają do tego wydajnej pomocy"63. Autor ten pisze, że w dokonywaniu perwersji przejętego przez narodowych socjalistów porządku prawnego udział brały wszystkie instytucje państwowe i całe środowisko prawnicze. Ustawodawstwo, orzecznictwo sądowe, administracja i nauki prawne wniosły swój istotny wkład do tego procesu. Zrobili oni nawet więcej, aniżeli władza oczekiwała od sędziów, prokuratorów, urzędników administracji i profesorów ${ }^{64}$.

\subsection{2 .}

Juryści Rzeszy nie zdołali jednak zyskać pełnego zaufania Hitlera, niemającego o nich nigdy dobrego zdania, gdyż ci byli dla niego stale „podejrzani i uciążliwi [suspekt und lästig]"65. Nieprzychylny pogląd Führera o prawnikach długo był

60 R. Lehnert, K. Schäfer, Kleines Strafrechts-Lehrbuch (Strafrecht und Strafprozeß) für Polizei und Gendarmerie, Berlin 1939, s. 14.

61 K. Ambos, op. cit., s. 43.

62 Ibidem, s. 99.

63 B. Rüthers, op. cit., s. 133.

64 Ibidem, s. 121.

65 D. Schenk, Die Post von Danzig. Geschichte eines deutschen Justizmords, Reinbek bei Hamburg 1995, s. 165. 
znany tylko jego najbliższemu otoczeniu, tworzącemu wewnętrzny krąg władzy. Dlatego zaskoczeniem, szczególnie dla prawników oddanych narodowosocjalistycznemu wymiarowi sprawiedliwości i przekonanych, że odczytują intencje i skrupulatnie spełniają oczekiwania przywódcy, było jego publiczne przemówienie wygłoszone w Reichstagu 26 kwietnia 1942 roku. Hitler mówił w nim o służebnej roli sędziów wobec narodu. Twierdzenie to zawarł w następującym fragmencie swego wywodu:

Oczekuję również, że niemiecki wymiar sprawiedliwości zrozumie, iż naród nie istnieje dla niego, lecz on istnieje dla narodu i że świat nie może zginąć dlatego, że istnieje prawo formalne. Przeciwnie, Niemcy muszą przetrwać niezależnie od formalnego pojmowania prawa przez wymiar sprawiedliwości. [...] Od tej chwili będę ingerował i pozbawiał stanowisk sędziów, którzy w oczywisty sposób nie rozumieją nakazów chwili ${ }^{66}$.

\section{Sondergericht Breslau i stosowanie przez niego Polenstrafrechtsverordnung}

\section{1. „Zdrowe poczucie narodowe” sędziów sądu specjalnego we Wrocławiu}

Przemówienie Führera odbiło się szerokim echem i musiało być znane także sędziom Sondergerichtu we Wrocławiu, co uzasadnia podjętą w niniejszym tekście analizę ferowanych przez nich zgodnie z ,nakazem chwili” wyroków, z powołaniem się na prawo karne dla Polaków i Żydów.

Rozporządzenie z 4 grudnia 1941 roku o postępowaniu karnym przeciwko Polakom i Żydom na przyłączonych do Rzeszy terenach wschodnich ${ }^{67}$ (Polenstrafrechtsverordnung) nie zawierało norm prawnokarnych w rozumieniu przyjętym przez klasyczną niemiecką szkołę prawa karnego, lecz ogólne wytyczne dla sędziów, jak mają karać wskazanych w tytule dokumentu podsądnych. Autorem projektu tego rozporządzenia był Franz Schlegelberger (1876-1970), od 1931 roku sekretarz stanu w ministerstwie sprawiedliwości, a w latach 1941-1942 szef tego resortu. Przygotowane przez niego wytyczne w formie klauzul generalnych wskazywały sędziom, że ich zadaniem jest drakońskie karanie Polaków i Żydów żyjących w okupowanym kraju, którym nakazano na wstępie ,zaniechać wszystkiego, co szkodzi powadze [Hoheit] Rzeszy Niemieckiej i uznaniu [Ansehen] dla Narodu Niemieckiego" (Teil 1 Ziffer I Absatz 1.). Przepis Teil 4. Ziffer XIV Absatz 2. stanowił o „rozszerzeniu obszaru zastosowania” także na Polaków i Żydów, którzy w dniu „1 września 1939 r. mieli miejsce zamieszkania lub stałego pobytu

66 Cyt. za: D. Schenk, Polska Poczta..., s. 171.

67 Strafrechtspflege gegen Polen und Juden in den eingegliederten Ostgebieten, vom 4.12.1941 Reichsgesetzblatt I, S. 759. 
w byłym polskim Państwie i popełnili czyn karalny na innym obszarze Rzeszy Niemieckiej aniżeli włączone tereny wschodnie" ${ }^{68}$. Przepis ten legitymował zatem karanie także polskich robotników przymusowych wywiezionych do niewolniczej pracy w Rzeszy, gdzie doszłoby do popełnienia przez nich czynów podlegających represji ze strony sądów specjalnych.

Generalną zasadą było karanie śmiercią, a jedynie w wyjątkowych przypadkach maksymalnie dziesięcioletnim pobytem w obozie karnym (co faktycznie oznaczało tylko odłożone w czasie uśmiercanie), Polaków i Żydów, którzy:

[...] przez nienawistne albo podburzające zachowanie wykazują wrogie wobec Niemców nastawienie, a w szczególności wypowiadają się wrogo przeciw Niemcom, zdzierają lub uszkadzają publiczne ogłoszenia niemieckich władz lub służb albo przez inne swe zachowania obniżają lub szkodzą poważaniu [Ansehen] lub dobru [Wohl] Niemieckiej Rzeszy lub niemieckiego Narodu, Teil 1. Ziffer I Absatz 3 Polenstrafrechtsverordnung ${ }^{69}$.

Obłęd ustanowionego bezprawia wynikał z tego, że karze śmierci podlegali Polacy wysiedlani z ich mieszkań i gospodarstw rolnych w okupowanym kraju, deportowani do Rzeszy i przydzielani Niemcom do niewolniczej pracy, jeżeli w położeniu, w którym się znaleźli, w jakikolwiek sposób wykazaliby „wrogie niemczyźnie nastawienie" (deutschfeindliche Gesinnung). Nieszczęśnicy ci podlegali karze śmieci już w przypadkach desperackich prób oporu przy wywlekaniu ich siłą z domostw, na przykład ,uderzenia Niemca w nos"70.

68 Polenstrafrechtsverordnung, Teil 4. Ziffer XIV Absatz 2.

${ }^{69}$ Ogólnikowość tego przepisu zachwyciła R. Freislera, który uznał go za „cudowny” (wunderbare Bestimmung) i jako „typowe przypadki” (typische Fälle), w których powinien być stosowany, wskazał karanie za noszenie oznaczeń pozorujących niemiecką przynależność narodowościową lub obcowanie płciowe z Niemcem bądź Niemką. Cyt. za: I. Müller, op. cit., s. 167. Zob. także: W. Kulesza, Są Specjalny (Sondergericht) w Lodzi, [w:] K. Stefański et al., Gmach i jego tajemnice. Sąd Okręgowy w Łodzi 1917-2017, Łódź 2017, s. 72.

${ }^{70}$ W. Kulesza, Odpowiedzialność karna za zbrodnie sądowe prokuratorów III Rzeszy w Niemczech Zachodnich i Wschodnich, „Czasopismo Prawno-Historyczne” 2021, t. 73, z. 1, s. 86. Szczegółowo udokumentowany cel i przebieg wysiedleń Polaków, których gospodarstwa rolne i mieszkania zajmowali niemieccy osadnicy, przedstawiła Maria Wardzyńska w swoim perfekcyjnie udokumentowanym źródłowo dziele: eadem, Wysiedlenia ludności polskiej z okupowanych ziem polskich włączonych do III Rzeszy w latach 1939-1945, Warszawa 2017. Wysiedlenia odbywały się najczęściej nocą, a osobom, które zostały nimi objęte, pozostawiano dziesięć-piętnaście minut na zabranie odzieży, pieniędzy, żywności i opuszczenie domu, ponadto obrzucano je epitetami ,polska świnia” i wykrzykiwano: „żaden Polak nie będzie tu więcej mieszkać!” (ibidem, s. 50). W przypadkach prób obrony rodziny przed wysiedleniem i ukrywania się w pomieszczeniach gospodarczych niemieccy żandarmi schwytaną osobę „,bili tak długo, dopóki nie powiedziała gdzie ukrywają się pozostali członkowie rodziny" (ibidem, s. 214). Wysiedlanych wieziono do punktów zbornych, a następnie do obozów przesiedleńczych, w których dokonywano rewizji, zabierając żywność, pieniądze, obrączki, kolczyki i odzież, w tym nawet obuwie (ibidem, s. 205, 222). Przeprowadzano selekcję — osoby zdolne do pracy deportowano na roboty do Rzeszy, pozostałych wywożono do Generalnego Gubernatorstwa. Wielu deportowanych zmarło w czasie transportu w nieludzkich warunkach. Zob. także W. Kulesza, Wysiedlenia z Kraju Warty (Warthegau) w świetle procesu Gauleitera Artura Greisera, [w:] Ludność cywilna w łódzkich obozach przesiedleńczych, red. J. Żelazko, Łódź 2010, s. 33 n. 
Wyroki wydawane przez sąd specjalny we Wrocławiu zawierają w zasadniczych fragmentach uzasadnień swego rodzaju historyczno-prawne wynurzenia, wynikające z prawniczego „zdrowego poczucia narodowego” sędziów i mające objaśniać przyczyny, dla których ci skazywali polskich robotników przymusowych za wszelkie przejawy nieposłuszeństwa wobec Niemców, którzy stali się ich panami. W objaśnieniach sytuacji historycznej i prawnej sędziowie dokonywali perwersyjnej zamiany ról - Niemcy byli Bogu ducha winnymi ofiarami, natomiast pozbawieni wszelkich praw Polacy stanowili źródło zagrożenia i dlatego w przypadku niesubordynacji podlegali sądowej eksterminacji.

\subsection{Robotnik przymusowy jako „sabotażysta podburzający innych Polaków”}

W wyroku sądu specjalnego z 19 stycznia 1943 roku $^{71}$, w którego składzie znajdowali się Landgerichtsassessor dr von Döhren, Landgerichtsrat dr Rosner i Gerichtsassessor dr Hoffmann (oskarżenie reprezentował prokurator Gawellek), zawarto następującą historiozoficzną refleksję:

Naród niemiecki toczy ciężką, narzuconą mu przez wrogów walkę o istnienie. Ponieważ mężczyźni zdolni do noszenia broni znajdują się na froncie i tam bronią ojczyzny z orężem w ręku, Niemcy zmuszone są do zatrudniania cudzoziemskich sił roboczych. Należy od nich wymagać bezwzględnej dyscypliny, aby porządek w kraju nie uległ załamaniu. Oskarżony nie tylko nie chciał zastosować się do oczywistych zasad, lecz umyślnie buntował się przeciwko nim ${ }^{72}$.

Takie było uzasadnienie skazania na karę śmierci trzydziestojednoletniego Bolesława Świętka, wywiezionego w 1942 roku na roboty przymusowe i przydzielonego do przedsiębiorstwa budowlanego Pawła Bergera w Szprotawie. Oskarżenie zarzuciło mu, że:

— pomimo wielokrotnych ostrzeżeń i pouczeń sporządzał mieszaninę betonową w niewłaściwych proporcjach i nakłaniał do tego samego drugiego Polaka;

— przed wieczorem często zakopywał w złożu żwiru taczki z zaprawą cementową, aby jej nie przerabiać na betonowe rury;

- przy budowie mostu ładował taczki powoli i przez to zakłócał prace;

- odmówił wykonywania pracy przy oczyszczaniu rowów odwadniających, twierdząc, że musi mieć do tego gumowe buty, a innym Polakom powiedział: „Wy głupie psy, dlaczego wykonujecie tę pracę! To nie jest robota dla Polaków, lecz dla Niemców";

- samowolnie oddalał się od miejsca pracy, a zwracającego mu uwagę niemieckiego brygadzistę Lemkego nazwał „sk****synem” i „Cyganem”;

71 Wyrok w sprawie nr 42 Sg 15 KLs 283/716/42, cyt. za: W. Lemiesz, op. cit., s. 132 n.

72 Ibidem, s. 134. 
— przyznał się Lemkemu, że melodia, którą gwizdał przy pracy, to Jeszcze Polska nie zginęla ...;

Oskarżonego, zaprzeczającego wszystkim zarzutom, sędziowie uznali za winnego, ponieważ: „Poprzez swoje zachowanie się w jak najcięższy sposób ugodził w powagę i dobro państwa niemieckiego, a poprzez nienawistną oraz podburzającą działalność wykazał ordynarne antyniemieckie nastawienie" ${ }^{\text {"73 }}$. W ten sposób uzasadniono zastosowanie $\mathrm{w}$ tej sprawie Polenstrafrechtsverordnung, z przepisem wskazującym sędziom, jak generalnie mają postępować z Polakami mającymi deutschfeindliche (antyniemieckie) nastawienie - Teil 1. Ziffer I Absatz 3. Sędziowie Sondergerichtu napisali o oskarżonym, że „W interesie utrzymania porządku w kraju takie elementy jak on nie mogą być w żadnym wypadku tolerowane". Dlatego na podstawie wyżej wzmiankowanych regulacji prawnych oskarżony „musi być skazany na śmierć”. Po miesiącu od wydania rozstrzygnięcia nadeszła decyzja ministra sprawiedliwości Ottona Thieracka z 19 lutego 1943 roku o nieskorzystaniu przez niego z prawa łaski, co było równoznaczne z zezwoleniem na wykonanie wyroku ${ }^{74}$.

\subsection{Para Polaków uznana za „zbrodniarzy posługujących się przemocą"}

Wyrokiem z 10 grudnia 1942 roku Sondergericht Breslau skazał spodziewających się wspólnego dziecka robotników przymusowych — dwudziestoośmioletnią Annę Zarembę i osiemnastoletniego Emila Gwiszcza, skierowanych do pracy w gospodarstwie rolnym Niemki o nazwisku Weise. Sędziami byli Landgerichtsrat dr Rosner, Landgerichtsrat dr Kunibert Stuhldreer i Landsgerichtsrat Fuchs, zaś funkcję oskarżyciela pełnił, tak jak w przypadku Świątka, prokurator Gawellek ${ }^{75}$.

73 Ibidem, s. 134.

74 Przepis § 453 StPO stanowił, że ,wyroki śmierci nie wymagają zatwierdzenia dla ich wykonania” i równocześnie zastrzegał, że ich ,wykonanie jest dopuszczalne dopiero wtedy, gdy nadejdzie decyzja władzy uprawnionej do ułaskawienia, że z przysługującego jej uprawnienia do ułaskawienia nie chce uczynić użytku”. Hitler jako ,władza uprawniona”, zachowując swe prawo do ułaskawiania skazanych, przekazał w 1935 roku ministrowi sprawiedliwości Rzeszy uprawnienie do wydawania decyzji odmownych. Postępowanie ułaskawieniowe wszczynano formalnie z urzędu, a właściwy miejscowo wyższy prokurator dołączał do wyroku swoje stanowisko. W sprawie Świątka nadprokurator Kosche napisał, że „wyrok nie nasuwa żadnych zastrzeżeń, gdyż jest on zgodny z formalnymi i materialnymi wymogami obowiązującego prawa"; zob. W. Lemiesz, op. cit., s. 134. Następnie sprawę przekazano, zgodnie z trybem postępowania, prokuratorowi generalnemu we Wrocławiu, który ocenił, że „ordynarny sposób postępowania Polaka nie daje podstaw do ułaskawienia”. W ministerstwie sprawiedliwości przygotowujący „,przedłożenie” dla ministra referent uznał skazanego za „fanatycznego, nienawidzącego Niemców Polaka”, zalecając wykonanie wyroku; zob. ibidem. Od 1936 roku podstawową formą wykonywania wyroków śmierci w Rzeszy było ścięcie na gilotynie; H. Schlüter, op. cit. s. 143, przypis 603.

75 Wyrok w sprawie nr 42 Sg KLs 206/42, cyt. za: W. Lemiesz, op. cit., s. 135 n. 
Ogólne stanowisko sądu w rozpatrywanej sprawie zawarte zostało we fragmencie uzasadnienia wyroku:

Naród niemiecki toczy ciężką walkę o swą egzystencję. Mężczyźni zdolni do pracy i noszenia broni są na froncie. Wśród nich małżonek pani Weise. Pozostałe w domu kobiety muszą równocześnie ciężko pracować w rolnictwie, aby zapewnić narodowi środki żywności. Przy wywołanym przez wojnę braku sił roboczych są one w znacznej mierze zdane na pomoc cudzoziemskich robotników; to znowu wymaga surowszego posłuszeństwa ze strony obcych robotników; przy wykroczeniach przeciwko dyscyplinie lub nawet niechęci z ich strony nakazane jest orzekanie najcięższych $\mathrm{kar}^{76}$.

Oskarżonej Polce zarzucono, że chwyciła łopatę i groziła nią niemieckiej gospodyni, bo ta miała ją źle traktować, a 28 marca 1942 roku nie spełniła polecenia wycięcia zgniłej części buraka, znalezionego przez panią domu w żłobie, lecz splunęła i szarpała się z kobietą, za co została uderzona ręką w twarz. Podsądna twierdziła na swą obronę, że w przygotowanej przez nią paszy nie było zgniłego buraka, a gospodyni zadała jej silny cios, po którym A. Zaremba splunęła, ale nie na Niemkę. Ta zaś biła ją, szarpała za włosy, wypchnęła na podwórko, gdzie uderzyła ją tak silnie, że Polka upadła pod wóz i prosiła, żeby jej nie bito. Przyznała, że użyła wyrazu „świnia”, na co usłyszała od gospodyni: „Muszę cię zabić”. Oskarżona mówiła o stałym szykanowaniu jej przez Weise i niewystarczającym pożywieniu, jakie otrzymywała mimo faktu, że była w ciąży. Z głodu i przepracowania opuchły jej nogi.

Oskarżonemu Polakowi zarzucono, że wpadł w złość, słysząc, jak Niemka Weise urąga polskiej robotnicy i rozbił dwie filiżanki, zaś 28 marca 1942 roku nazwał przybyłego w celu interwencji sąsiada o nazwisku Muecke „niemiecką świnią", za co został uderzony ,drewnianym chodakiem w twarz, tak że mu poszła krew z nosa”. Wtedy Gwiszcz chwycił długą drewnianą żerdź, ,wpadł przy tym w taką złość i podniecenie, że świadek Muecke jak najpoważniej przypuszczał, że zostanie uderzony [tą - W. K.] żerdzią" 77 . Polski robotnik przymusowy przyznał się, że stłukł dwie filiżanki, gdyż Weise biła Polkę, która miała spuchnięte nogi i nie mogła pracować. Zaprzeczył, jakoby nazwał świadka Mueckego „niemiecką świnią", a oszołomiony zadanym przezeń niespodziewanym ciosem chodakiem, oparł się o drzewo i chwycił żerdź, ale nie miał zamiaru jej wykorzystywać do ataku na sąsiada gospodyni.

Sąd uznał, że oboje oskarżeni dopuścili się uszkodzenia ciała w stosunku do Niemców, a poza tym grozili im. Za podstawę kwalifikacji prawnokarnej przypisanych im zachowań przyjęto rozporządzenie przeciwko ,zbrodniarzom posługującym się przemocą" z 5 grudnia 1939 roku $^{78}$. Zastosowanie tego aktu prawnego dowodziło morderczej determinacji sędziów, nie zważających na to, że jego treść w żadnym fragmencie nie przystawała do zarzutów, nawet uznanych za

76 Ibidem, s. 137.

77 Ibidem, s. 136.

78 Verordnung gegen Gewaltverbrechen vom 5. December 1939, RGB1. I, S. 2378. 
udowodnione. Przepis definiował bowiem kategorię sprawców jako dopuszczających się ,aktów gwałtu z bronią”: „§ 1 (1) Kto przy zgwałceniu, rozboju ulicznym, rabunku banku lub przy innym ciężkim akcie gwałtu posługuje się bronią palną, sieczną lub kolną, lub innym równie niebezpiecznym środkiem lub zagraża życiu lub zdrowiu innego, będzie karany śmiercią". Uzasadnienie wyroku zamykało zdanie ,Zgodnie z tym należało orzec $\mathrm{w}$ stosunku do obojga [oskarżonych - W.K.] karę śmierci" ${ }^{\prime 79}$.

Rekonstrukcja rozumowania sądu w referowanej sprawie wymaga zaznaczenia na wstępie, że w wielu przypadkach sędziowie sondergerichtów, kierujący się ,zdrowym poczuciem narodowym”, najpierw decydowali o karze śmierci, po czym dokonywali subsumpcji czynu przypisanego oskarżonemu pod przepis, który ją przewidywał, mimo że nie opisywał on zachowania, za które karali. W przypadku E. Gwiszcza, który w czasie popełnienia przestępstwa nie miał jeszcze 18 lat (urodził się 17 listopada 1924 roku, zarzucanych mu czynów miał dopuścić się w marcu i kwietniu 1942 roku, a więc na pół roku przed osiągnięciem pełnoletności), czyli był nieletni w rozumieniu ,prawa sądowego nieletnich" ${ }^{80}$. Ustawa ta stanowiła w $\S 9$, że osobie małoletniej za zachowanie zagrożone wyrokiem śmierci lub dożywotniego ciężkiego więzienia zamiast tego wymierza się karę więzienia od roku do dziesięciu lat. Zakwalifikowanie czynów przypisanych oskarżonemu Polakowi jako aktów gwałtu z użyciem broni oznaczało uznanie go za „ciężkiego przestępcę" (Schwerverbrecher). Zarządzenie o ochronie przeciwko nieletnim głosiło, że wobec nieletniego ciężkiego przestępcy, który ukończył 16 lat, mogą zostać zastosowane kary i środki poprawy grożące dorosłemu sprawcy ${ }^{81}$. Polenstrafrechtsverordnung stanowił w przepisie Teil 1. Ziffer III Absatz 2, że Schwerverbrecher może zostać skazany na karę śmierci także w sytuacji, gdy nie osiągnął jeszcze pełnoletności. Przepis ten został przywołany w rozstrzygnięciu sądu jako podstawa do wymierzenia takiej kary. Minister sprawiedliwości Rzeszy O. Thierack nie skorzystał z prawa łaski i wyrok został wykonany. Według prokuratorskiego raportu egzekucja trwała dziewięć sekund ${ }^{82}$.

Wyrok na Annie Zarembie nie został wykonany, ponieważ § 453 StPO stanowił jednoznacznie, że „na osobach ciężarnych nie dozwala się wykonywania kary śmierci”. Ministerialną decyzją zamieniono jej karę na dziesięć lat obostrzonego obozu karnego, co de facto oznaczało śmierć w ciągu kilku miesięcy ${ }^{83}$.

79 W. Lemiesz, op. cit., s. 137.

80 Jugendgerichtsgestz vom 16 Februar 1923, RGB1. I, S. 135. Przepis $§ 1$ stanowił że „Nieletnim [Ein Jugentlicher] w rozumieniu tej ustawy jest, kto ma czternaście lat, lecz jeszcze nie osiemnaście lat".

$81 \S 1$ (1) Verordnung zum Schutz gegen jugendliche Schwerverbrecher vom 4 Oktober 1939, RGB1 I, S. 2000.

82 W. Lemiesz, op. cit., s. 137.

83 Ibidem. 


\subsection{Polak skazany za groźby i antyniemieckie wypowiedzi}

Wyrokiem tego samego Sondergerichtu ${ }^{84}$, w którego składzie zasiadali Landesgerichtsdirektor dr Teuchert i Landgerichtsrat Garn (oskarżał prokurator Schoengarth), z 21 czerwca 1943 roku skazany zostali Stanisław Ślusarski, lat 37, i jego o rok młodsza żona, Stanisława. Oboje i ich dwunastoletni syn Tadeusz zostali wywiezieni do Niemiec jako robotnicy przymusowi przydzieleni do gospodarstwa Ewalda Schmidta.

Oskarżonemu Śliwińskiemu prokurator zarzucił, że ten:

— groził, że zabije Niemca Baumgartena, jeżeli ten jeszcze raz zbije jego żonę, którą wypędził ze swego pola, podejrzewając, że zamiast pilnować krów Schmidta odciąga ona ,polskich robotników rolnych od pracy”;

— chwycił widły i zamierzył się na Schmidta (przeszkodziła mu w tym żona), gdy ten zmuszał niemającego butów Tadeusza Ślusarskiego do udeptywania nawozu, razem z wierzgającym wołem;

— postępował okrutnie z bydłem;

— powiedział, że „w jego wsi w Polsce rolnicy zostali wywłaszczeni i wysłani na roboty do Niemiec, zaś Niemcy przywłaszczyli sobie polską własność", a usłyszawszy od Schmidta, że „Polacy są sobie sami winni, gdyż judzili przeciwko Niemcom i wszczęli wojnę”, ripostował, że „gdy jego chłopiec dorośnie, zrobi w Polsce powstanie".

Oskarżony zaprzeczył, jakoby kiedykolwiek miał grozić Schmidtowi, który pobił jego dziecko, niepotrafiące poradzić sobie z wołem, i zagroził chłopcu: ,Jeżeli tego nie rozumiesz, to będę ubijał nawóz twoją czaszką". Przestraszony chłopiec uciekł do ojca, który zauważył, że ,twarz jego była cała w błocie, a z nosa ciekła krew”. Gospodarz powiedział Ślusarskiemu: „Przeklęty Polaku, połamię ci wszystkie kości i żebra”, a następnie uderzył go kijem w twarz. Poprzedniego dnia Schmidt odmówił wydania bosemu Tadeuszowi kartki na buty i pieniędzy na ich zakup ${ }^{85}$.

W akcie oskarżenia zachowanie robotnika przymusowego zostało określone jako „typowo polskie — złodziejskie, zakłamane i niekiedy porywcze" ${ }^{86}$. Sąd, uznając winę Ślusarskiego za udowodnioną, napisał w wyroku, że jest to ,polski brutal, który nie cofa się przed żadnym czynem gwałtu wobec zwierzęcia czy człowieka". Przypisując mu nieprzychylne zachowania i wypowiedzi w stosunku do Niemców (do czego oskarżony nie przyznał się przed sądem), sędziowie uznali, że za ,groźby i antyniemieckie wypowiedzi jedyną karą wchodzącą w grę może być kara śmierci”.

Żona Ślusarskiego, Stanisława, została skazana skazana na rok obozu karnego za „zwymyślanie dwóch Niemek i pokazanie im języka”.

${ }^{84}$ Wyrok w sprawie $\mathrm{nr} 42 \mathrm{Sg} 15 \mathrm{KLs}$ 77/43, cyt. za: W. Lemiesz, op. cit., s. 138 n.

85 Ibidem, s. 139.

86 Ibidem. 


\section{Uwagi końcowe}

Podpisujący się po tymi wyrokami sędziowie mieli świadomość, że dokonują zabójstw Polaków, wobec których III Rzesza, pozbawiając ich własności i wolności, deportując $\mathrm{z}$ okupowanego kraju do pracy przymusowej i zamieniając w niewolniczą siłę roboczą, złamała podstawowe zasady przyjęte w Dziale III Konwencji Haskiej z 1907 roku „o władzy wojennej na terytorium państwa nieprzyjacielskiego". Wyroki, które wydali, są typowymi przykładami przestępczego naginania prawa w rozumieniu obowiązującego w tym czasie przepisu § 336 StGB. Powojenny wymiar sprawiedliwości określił, że przestępcze naginanie prawa przez sędziów III Rzeszy polegało zarówno na fałszowaniu istoty sprawy (Sachverhaltsverfälschung) lub fałszywym zastosowaniu prawa (falsche Rechtsanwendung), jak i nadużyciu prawa do wymierzania kary skazanemu według sędziowskiego uznania (Ermessensmißbrauch) ${ }^{87}$. Równocześnie sędziowie uniknęli odpowiedzialności za tak rozumiane naginanie prawa, ponieważ wprowadzono w ich przypadku warunek udowodnienia im, że czynili to z zamiarem bezpośrednim. Zamiar ewentualny uznano za niewystarczający. W praktyce oznaczało to, że konsekwencje zabójstwa poprzez niesłuszne skazanie na śmierć mógłby ponieść tylko ten sędzia, który sam przyznałby się, że był świadom czynionego w ten sposób bezprawia i chciał je urzeczywistnić w swej decyzji. Ponieważ nie było takiego przypadku, sędziów III Rzeszy ochronił „,przywilej sędziowski”, polegający na zwolnieniu ich od odpowiedzialności za skutki wydawanych przez nich wyroków ${ }^{88}$.

Nasuwa się tutaj refleksja, że sędziów karzących w ich „zdrowym poczuciu narodowym" obroniła po wojnie umiejętność odwracania rozumowania prawniczego, którą można by określić jako „moralnie chore poczucie zawodowe"89. Tezę Gustava Radbrucha (1878-1949), która miała otwierać drogę do ustalenia odpowiedzialności za morderstwa skazanych na karę śmierci, będące skutkiem naginania prawa w treści wyroków, odwrócono, nadając jej wręcz przeciwny normatywny sens i wyprowadzając z niej funkcję zamykającą (sperwirkung) możliwość przypisania im zabójstw podsądnych ${ }^{90}$.

Przywołani na wstępie M. Görtemaker i Ch. Safferling spośród wielu cech prawników wyróżnili specyficzną dla ich profesji umiejętność służenia każdej

87 Szerzej zob. W. Kulesza, Crimen laesae iustitiae..., s. 92.

88 Szerzej W. Kulesza, Odpowiedzialność karna za zbrodnie sądowe sędziów III Rzeszy w Niemczech Zachodnich i Wschodnich, „Czasopismo Prawno-Historyczne” 2021, t. 73, z. 2, s. 63-96.

${ }^{89}$ O motywacji wydających zbrodnicze wyroki sędziów zob. W. Kulesza, Okupacyjny nadburmistrz i sędziowie Sadu Specjalnego w Toruniu (czyli o paradoksach historyczno-prawnych), „Studia Iuridica Toruniensia” 27, 2020, s. 157.

90 Współczesne zasady odpowiedzialności karnej sędziów za naginanie prawa - zob. W. Kulesza, Sędziowskie naginanie prawa w świetle niemieckiego prawa karnego, [w:] Artes Serviunt Vitae Sapientia Imperat. Proces karny sensu largo. Rzeczywistość $i$ wyzwania. Księga jubileuszowa Profesora Tomasza Grzegorczyka z okazji 70. urodzin, red. J. Kasiński, A. Małolepszy, P. Misztal, R. Olszewski, K. Rydz-Sybilak, D. Świecki, Warszawa-Łódź 2019, s. 646 n. 
władzy w ramach posiadanych przez nich kompetencji zawodowych. Gdy załamuje się system państwa totalitarnego, pracujący dla niego juryści, z niezmąconą świadomością swej przydatności w współtworzeniu i stosowaniu prawa, włączają się do funkcjonowania wymiaru sprawiedliwości w demokratycznym państwie. Nie angażując swych sumień, technicy prawa potrafią wykazać swoje pełne zdolności także w realiach państwa prawnego. Równocześnie umiejętnie wykorzystują jego zasady, żeby zapewnić sobie uniknięcie odpowiedzialności za wcześniejsze współdziałanie w realizacji systemowego bezprawia w ustroju totalitarnym. Ich doświadczenie jest niezmiennie postrzegane jako zaleta i gwarancja profesjonalizmu zawodowego. M. Görtemaker i Ch. Schafferling potwierdzają swoje tezy, przedstawiając powojenne kariery nazistowskich prawników w ministerstwie sprawiedliwości Republiki Federalnej Niemiec. Jako przyczynek do ich wielkiego dzieła trzeba przywołać ustalenia Wiktora Lemiesza na temat działalności po 1945 roku sędziów Sondergerichtu Breslau, którzy podpisywali się pod omówionymi powyżej wyrokami ${ }^{91}$.

\section{Bibliografia}

Ambos K., Nationalsozialistisches Strafrecht, Baden-Baden 2019.

Auerbach H., Ermächtigungsgesetz, [w:] Enzyklopädie des Nationalsozialismus, red. H. Benz, H. Graml, H. Weiß, München 1997.

Dalcke A., Fuhrmann E., Krug K., Schäfer K., Strafrecht und Strafverfahren, Berlin-München 1940. Dalcke A., Schäfer K., [w:] A. Dalcke, E. Fuhrmann, K. Krug, K. Schäfer, Strafrecht und Strafverfahren, Berlin-München 1940.

„Deutsche Juristen-Zeitung” 1933, nr 7.

Die Rosenburg. Das Bundesministerium der Justiz und die NS-Vergangenheit - eine Bestandsaufnahme, red. M. Görtemaker, Ch. Safferling, Bonn 2013.

Görtemaker M., Safferling Ch., Die Akte Rosenburg. Das Bundesministerium der Justiz und die NS-Zeit, München 2016.

Handbuch der Justiz, Die Träger und Organe der Rechtsprechenden in der Bundesrepublik Deutschland, Hamburg-Berlin 1958, 1962.

Hasse N., Denunziantentum, [w:] Enzyklopädie des Nationalsozialismus, red. H. Benz, H. Graml, H. Wei $\beta$, München 1997.

Hitler A., Mein Kampf. Zwei Bände in Einem Band, München 1944.

Jońca K., Koncepcje narodowosocjalistycznego prawa w Trzeciej Rzeszy, „Studia nad Faszyzmem i Zbrodniami Hitlerowskimi” 3, 1977.

Klee E., Das Personenlexikon zum Dritten Reich. Wer war was vor und nach 1945?, Frankfurt am Main 2003.

91 W. Lemiesz ustalił status i funkcje pełnione po wojnie przez prawników III Rzeszy na podstawie oficjalnego wydawnictwa Handbuch der Justiz, Die Träger und Organe der Rechtsprechenden in der Bundesrepublik Deutschland, Hamburg-Berlin 1958, 1962. Autor ten podaje że dr Rosner - Landgerichtsrat w Baden-Baden — przeszedł na emeryturę w 1960 roku. (Lemiesz, op. cit., 132). W 1962 roku w sędziowskiej służbie pozostawali dr Kunibert Stuhldreer (Amtsgerichtsrat $\mathrm{w}$ Landshucie), dr Teuchert (Landsgerichtsrat w Stuttgarcie), sędzia Garn (Amtsgerichtsrat w Büdingen), prokurator Schoengarth (Amtsgerichtsrat w Hagen) - ibidem, s. 132, 135, 138. 
Kulesza W., Crimen laesae iustitiae. Odpowiedzialność karna sędziów i prokuratorów za zbrodnie sądowe wedtug prawa norymberskiego, niemieckiego, austriackiego i polskiego, Łódź 2013.

Kulesza W., Odpowiedzialność karna za zbrodnie sądowe prokuratorów III Rzeszy w Niemczech Zachodnich $i$ Wschodnich, „Czasopismo Prawno-Historyczne” 2021, t. 73, z. 1.

Kulesza W., Odpowiedzialność karna za zbrodnie sądowe sędziów III Rzeszy w Niemczech Zachodnich i Wschodnich, „Czasopismo Prawno-Historyczne” 2021, t. 73, z. 2.

Kulesza W., Okupacyjny nadburmistrz i sędziowie Sadu Specjalnego w Toruniu (czyli o paradoksach historyczno-prawnych), „Studia Iuridica Toruniensia” 27, 2020.

Kulesza W., ,, Polskie obchody” rocznicy urodzin Hitlera w świetle prawa karnego III Rzeszy, Republiki Federalnej Niemiec i Polski, „Państwo i Prawo” 2018, nr 7.

Kulesza W., Sąd Specjalny (Sondergericht) w Łodzi, [w:] K. Stefański, J. Machut-Kowalczyk, J. Wiewiórski, Gmach i jego tajemnice. Sąd Okręgowy w Łodzi 1917-2017, Łódź 2017.

Kulesza W., Sędziowskie naginanie prawa w świetle niemieckiego prawa karnego, [w:] Artes Serviunt Vitae Sapientia Imperat. Proces karny sensu largo. Rzeczywistość $i$ wyzwania. Księa jubileuszowa Profesora Tomasza Grzegorczyka z okazji 70. urodzin, red. J. Kasiński, A. Małolepszy, P. Misztal, R. Olszewski, K. Rydz-Sybilak, D. Świecki, Warszawa-Łódź 2019.

Kulesza W., Wysiedlenia z Kraju Warty (Warthegau) w świetle procesu Gauleitera Artura Greisera, [w:] Ludność cywilna w tódzkich obozach przesiedleńczych, red. J. Żelazko, Łódź 2010.

Lehnert R., Schäfer K., Kleines Strafrechts-Lehrbuch (Strafrecht und Strafprozeß) für Polizei und Gendarmerie, Berlin 1939.

Lemiesz W., Paragraf i zbrodnia, Warszawa 1963.

Lobe A., [w:] L. Ebermayer, A. Lobe, W. Rosenberg, Reichs-Strafgesetzbuch (Leipziger Kommentar), Berlin-Leipzig 1925.

Marxen K., Schlüter H., Terror und „,Normalität”. Urteile des nationalsozialistischen Volksgerichtschof: Eine Dokumentation, Recklinghausen 2004.

Müller I., Furchtbare Juristen. Die unbewältigte Vergangenheit unserer Justiz, München 1989.

Pommerin R., Machtergreifung, [w:] Enzyklopädie des Nationalsozialismus, red. H. Benz, H. Graml, H. Wei $\beta$, München 1997.

Proces Artura Greisera przed Najwyższym Trybunatem Narodowym, Warszawa 1946.

Ritter E., Justiz und innere Verwaltung, [w:] Enzyklopädie des Nationalsozialismus, red. H. Benz, H. Graml, H. Wei $\beta$, München 1997.

Rosenburg - Federalne Ministerstwo Sprawiedliwości Niemiec w cieniu narodowosocjalistycznej przeszłości, przeł. M. Bainczyk, Kraków 2019.

Rüthers B., Die Gesetzgebung — Vom „Dritten Reich“ zur Bundesrepublik Deutschland. Vierzehn Hypothesen, [w:] Die Rosenburg. Das Bundesministerium der Justiz und die NS-Vergangenheit - eine Bestandsaufnahme, red. M. Görtemaker, Ch. Safferling, Bonn 2013.

Ryszka F., Państwo stanu wyjątkowego. Rzecz o systemie państwa i prawa Trzeciej Rzeszy, Wrocław-Łódź 1985.

Schenk D., Die Post von Danzig. Geschichte eines deutschen Justizmords, Reinbek bei Hamburg 1995.

Schenk D., Poczta Polska w Gdańsku. Dzieje pewnego niemieckiego zabójstwa sądowego, przeł. W. Tycner, J. Tycner, Gdańsk 1999.

Schlüter H., ,.... für die Menschlichkeit im Strafmaß bekant...”. Das Sondergericht Litzmannstadt und sein Vorsitzender Richter, Recklinghausen 2005.

Schmitt C., Das Gesetz zur Behebung der Not von Volk und Reich, „Deutsche Juristen-Zeitung“ 1933, $\mathrm{nr} 7$.

Schmitt C., Nationalsozialismus und Rechtstaat, „Juristische Wochenschrift“ 1934, nr 12/13.

Schmitt C., Neue Leitsetze für die Rechtspraxis, „Juristische Wochenschrift“ 1933, nr 50.

Wardzyńska M., Wysiedlenia ludności polskiej z okupowanych ziem polskich właczonych do III Rzeszy w latach 1939-1945, Warszawa 2017. 